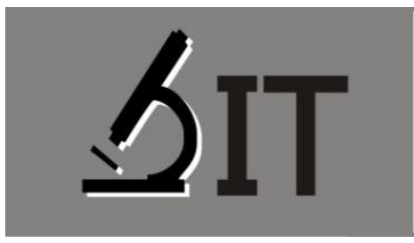

p-ISSN : 2597-8977

e-ISSN : $2597-8985$

Sariayuningsi Amalia*) Universitas Negeri Makassar

Abdul Mun'im Universitas Negeri Makassar

Sitti Rahma Yunus Universitas Negeri Makassar

*) Correspondence Author: sariayuamalia12@gmail.com
JIT 2 (1) (2018) 46-56

JURNAL IPA TERPADU

http://ojs.unm.ac.id/index.php/ipaterpadu

\section{PENGARUH METODE PEMBELAJARAN OUTDOOR LEARNING TERHADAP MOTIVASI DAN HASIL BELAJAR PESERTA DIDIK KELAS VII SMP NEGERI 15 MAKASSAR (STUDI PADA MATERI POKOK INTERAKSI MAKHLUK HIDUP DENGAN LINGKUNGAN)}

Abstrak: Penelitian ini bertujuan untuk 1) mengetahui pengaruh metode Outdoor Learning terhadap motivasi belajar peserta didik kelas VII SMP Negeri 15 Makassar, 2) mengetahui pengaruh metode Outdoor learning terhadap hasil belajar peserta didik kelas VII SMP Negeri 15 Makassar. Penelitian dilakukan dengan menggunakan desain nonequivalent Grup Control Grup Design. Penelitian ini dilakukan di SMP Negeri 15 Makassar, Tahun ajaran 2017/2018. Pengambilan sampel menggunakan teknik purposive sampling. Sampel penelitian yang digunakan 30 orang pada kelas eksperimen dan 30 orang pada kelas kontrol. Instrumen yang digunakan adalah angket motivasi belajar dan lembar tes hasil belajar. Hasil belajar dianalisis dengan menggunakan $\mathrm{N}$-gain skor. Dari data hasil penelitian dapat disimpulkan bahwa motivasi kelas eksperimen lebih tinggi dari motivasi kelas kontrol. Selanjutnya, $\mathrm{N}$-gain hasil belajar peserta didik untuk kriteria tinggi mencapai 56,67\% persentasenya pada kelas eksperimen sedangkan pada kelas kontrol persentasenya hanya sebesar 20,00\%. Kriteria tinggi pada kategori $\mathrm{N}$-gain tersebut menunjukkan bahwa terjadi peningkatan hasil belajar yang lebih signifikan pada kelas eksperimen yang diajar menggunakan metode outdoor learning dibandingkan dengan kelas kontrol yang diajar tanpa menggunakan metode outdoor learning.

Kata Kunci: Metode Outdoor Learning, Motivasi belajar, Hasil belajar.

Abstract: This study aims to 1) to know the effect of Outdoor Learning method on the motivation of studying students of class VII of SMP Negeri 15 Makassar, 2) the influence of Outdoor learning method toward the learning outcomes of students of class VII of SMP Negeri 15 Makassar. The study was conducted using nonequivalent Design Group Control Group Design. This research was conducted in SMP Negeri 15 Makassar, academic year 2017/2018.b The Sampling using purposive sampling technique. The sample used 30 people in the experimental class and 30 people in the control class. From the data, it can be concluded that experiment class motivation is higher than control class motivation. Next, $\mathrm{N}$-gain learning outcomes of learners for high criteria reached $56.67 \%$ percentage in the experimental class whereas in the control class the percentage is only $20.00 \%$. The high criteria in the $\mathrm{N}$-gain category shows that there is a significantly improved learning result in the experimental class taught using the outdoor learning method compared to the control class taught without using the outdoor learning method.

Keyword: : Outdoor Learning Method, Learning Motivation, Learning Outcomes. 


\section{PENDAHULUAN}

Kurikulum pendidikan senantiasa selalu berubah setiap saat sesuai dengan perubahan zaman. Perubahan zaman adalah hal yang tidak bisa terlepas dari kehidupan masyarakat. Perubahan zaman telah memberikan dampak yang besar terhadap seluruh segi kehidupan masyarakat tidak terkecuali dalam segi pendidikan. Dewasa ini, masyarakat sebagai agen perubahan itu sendiri mulai berinovasi dan mulai menangkap akan adanya tantangan zaman. Pendidikan mencoba untuk menyikapi dilema tersebut, kemudian mengemasnya dalam sebuah konsep perubahan kurikulum. Isu - isu perubahan, fakta, dan realita kehidupan masyarakat serta isu - isu tantangan zaman dikemas sedemikian rupa sebagai dasar untuk mengembangkan sebuah kurikulum baru yang mencoba untuk menjawab tantangan zaman tersebut.

Sehingga sampailah pada kurikulum pendidikan yang terbaru yaitu Kurikulum 2013 yang berbasis kompetensi dan karakter. Implementasi kurikulum 2013 yang berbasis kompetensi sekaligus berbasis karakter, mengharapkan peserta didik mampu secara mandiri meningkatkan dan menggunakan pengetahuannya, mengkaji, dan menginternalisasi serta mempersonalisasi nilai nilai karakter dan akhlak mulia sehingga terwujud dalam perilaku sehari - hari. Berdasarkan edaran bahan uji publik Kurikulum 2013 terdapat empat fokus pengembangan kurikulum salah satunya adalah mengenai standar penilaian pendidikan. Di Indonesia Sistem Pendidikan Nasional telah mengadopsi taksonomi dalam bentuk rumusan sikap, pengetahuan dan keterampilan.

Kurikulum 2013 menekankan akan esensi pendekatan ilmiah di dalam setiap proses pembelajaran. Pendekatan ilmiah berpedoman pada teknik - teknik investigasi atas fenomena, gejalah alam, memdapatkan pengetahuan baru, atau menyunting dan mengkolaborasikan dengan pengetahuan sebelumnya. Salah satu pelajaran yang menggunakan pendekatan ilmiah tersebut adalah pelajaran IPA (IImu Pengetahuan Alam) terpadu dalam kurikulum 2013. Peserta didik diarahkan untuk mencari dan menemukan sendiri sehingga dapat membantu untuk memperoleh pemahaman yang lebih mendalam tentang alam sekitar. Peserta didik dapat memperoleh pengalaman langsung sehingga dapat menambah kekuatan untuk bisa menerima, menyimpan dan menerapkan, konsep yang telah dipelajarinya.

Materi pembelajaran juga harus disesuaikan dengan karakteristik kebutuhan peserta didik. Diketahui bahwa setiap daerah mempunyai karakterisktik lingkungan, baik alam maupun masyarakatnya. Materi pembelajaran yang disesuaikan dengan kebutuhan peserta didik akan menyebabkan peserta didik merasa bahwa mempelajari materi tersebut sangat berguna karena dapat dimanfaatkan dalam kehidupan sehari - hari mereka. Maka, mereka akan lebih termotivasi untuk aktif bekerja mencari pengetahuannya sendiri. Berdasarkan penelitian yang dilakukan oleh Pratama dkk (2016) tujuan dari pembelajaran IPA adalah untuk menciptakan agar peserta didik memiliki pengetahuan yang dapat bermanfaat yang digunakan dalam kehidupan sehari - hari atau alam sebagai salah satu sikap mensyukuri anugerah yang telah Tuhan berikan.

Berdasarkan hasil pengamatan diperoleh bahwa kegiatan belajar mengajar yang telah dilakukan di SMP Negeri 15 Makassar guru hanya memberikan sebatas pengantar materi kemudian meminta peserta didik untuk melakukan kegiatan pengamatan. Akan tetapi, banyak peserta didik yang dalam melakukan pengamatan pada materi gerak pada makhluk hidup dan benda hanya bermain dengan temannya yang lain. Untuk itu, pembelajaran menjadi kurang terarah. Suasana kelas yang panas, dan pembelajaran yang terus berlangsung di dalam kelas membuat peserta didik merasa bosan dan tidak memiliki motivasi untuk belajar, hal ini karena lingkungan belajar di dalam kelas yang kurang kondusif. Peserta didik merasa kesulitan untuk memahami materi yang disajikan. Pengamatan yang dilakukan oleh peserta didik hanya berlangsung di dalam kelas dengan jumlah peserta didik 30 orang melakukan pengamatan di dalam kelas membuat ruang gerak peserta didik menjadi terbatas.

Berdasarkan hasil wawancara yang telah dilaksanakan di SMP Negeri 15 Makassar bersama dengan guru IPA diperoleh informasi mengenai hasil belajar IPA yang masih rendah pada 17 orang 
peseta didik. Hal ini didasarkan pada pencapaian Kriteria Ketuntasan Minimum (KKM) mata pelajaran IPA yang diberikan oleh guru (75) 17 peserta didik masih mecapai nilai rata - rata hasil ulangan harian di bawah KKM yakni dengan skor rata - rata 60. Selain itu setelah menanyakan tentang motivasi belajar peserta didik khususnya untuk pelajaran IPA peserta didik masih kurang termotivasi dalam belajar IPA karena metode yang digunakan guru masih kurang bervariasi sehingga peserta didik kurang tertarik terhadap pembelajaran.

Menurut Nugroho dan Nur Rokhimah Hanik (2016) Permasalahan dalam pembelajaran perlu dicari solusi agar terjadi perbaikan dan peningkatan hasil belajar kognitif. Sebelum penentuan solusi terhadap permasalahan perlu mengetahui akar masalah. Pembelajaran yang terjadi di sekolah pada umumnya bukan hanya yang terjadi di SMP Negeri 15 Makassar tetapi di sekolah formal yang lain, cenderung dilakukan secara monoton, baik dilihat dari segi metode, strategi, model, pendekatan, media dan sumber belajar yang digunakan.

Usia peserta didik yang masih berada pada usia masa berpikir dari hal konkret menuju abstrak, memerlukan sesuatu yang realita sesuai dengan aslinya dan butuh pembuktian dalam setiap pembelajarannya. Sebuah pepatah Cina kuno mengungkapkan bahwa "I hear and I forget, I see and I remember, I do and I understand' (Rustaman, 2003).

Lingkungan di luar sekolah dapat dijadikan sebagai sumber belajar yang bersifat fakta, karena materi pembelajaran yang peserta didik pelajari di dalam kelas dapat ditemukan langsung di lapangan. Outdoor Learning merupakan pembelajaran yang mampu membuat peserta didik aktif dengan mengajak peserta didik mengidentifikasi secara langsung sehingga pembelajaran menjadi bermakna dan penguasaan konsep atau hasil belajar dapat diberdayakan. Dale (Nugroho, 2016) menyatakan bahwa orang akan mengingat 50\% dari yang didengar dan dilihat, tetapi orang akan mengingat 90\% dari yang telah dilakukan seperti mengerjakan sebuah tugas atau melakukan penyelidikan.

Selain itu, suasana di dalam kelas maupun di luar kelas perlu direncanakan dan dibangun sedemikian rupa dengan menggunakan model pembelajaran yang tepat agar peserta didik dapat memperoleh kesempatan berinteraksi satu sama lain sehingga peserta didik dapat memperoleh hasil belajar yang optimal. Berkembangnya penelitian dibidang pendidikan banyak ditemukan model - model pembelajaran baru yang dapat meningkatkan interaksi peserta didik dalam proses belajar mengajar. salah satu model pembelajaran yang dapat meningkatkan produktivitas belajar untuk kebermaknaan konteks pembelajaran adalah dengan menggunakan model Discovery Learning atau model penemuan. Model penemuan (Discovery Learning) merupakan salah satu model pembelajaran kognitif yang dikembangkan oleh Bruner. Model pembelajaran Discovery Learning mendorong peserta didik untuk mengidentifikasi apa yang ingin diketahui dilanjutkan dengan mencari informasi sendiri kemudian mengorganisasi apa yang mereka ketahui dan mereka pahami maka, materi pelajaran yang akan disampaikan tidak disampaikan dalam bentuk final. Sewaktu melakukan wawancara dengan guru IPA tentang model pembelajaran yang digunakan ternyata model pembelajaran yang digunakan di SMP Negeri 15 Makassar sudah menggunakan model pembelajaran Discovery Learning.

Model Discovery Learning yang digunakan guru pada sekolah SMP Negeri 15 Makassar didukung dengan metode konvensional yang selalu digunakan oleh guru dalam proses pembelajaran. Metode konvensional yang digunakan guru adalah metode ceramah. Dimana, kegiatan pembelajarannya masih terpusat pada guru sebagai pemberi informasi (bahan pembelajaran).

Berdasarkan persoalan yang dipaparkan di atas, maka penelitian ini difokuskan pada upaya penerapan metode Outdoor Learning. Inti dari pembelajaran ini adalah menggunakan media lingkungan sebagai sumber belajar karena lingkungan merupakan sumber media yang riil, bukan tiruan atau model sehingga pembelajaran menjadi lebih menarik, dengan metode di atas diharapkan dapat meningkatkan motivasi dan hasil belajar peserta didik. 
Adapun hasil penelitian yang mendukung yaitu Pratama dkk, (2016) menyatakan bahwa penerapan outdoor learning pendekatan JAS (Jelajah Alam Sekitar) di SDN Archamanik II menyebabkan adanya peningkatan hasil belajar peserta didik. Hasil penelitan selanjutnya ialah Amtonurajah dan Muhsinatun (2015) menyatakan bahwa melalui outdoor activity dapat meningkatkan keterampilan sosial peserta didik dalam pembelajaran IPS pada peserta didik kelas VII A SMP Negeri 1 Kaligondang Kabupaten Purbalingga. Peningkatan ini terbukti dari hasil rerata keterampilan sosial peserta didik meningkat terus dari siklus I, II, dan III melalui outdoor activity, sebagai metode pembelajaran, ditempuh dengan cara melakukan observasi atau outdoor dengan tujuan untuk melakukan interaksi sosial secara langsung.

Berdasarkan uraian di atas sangat perlu dilakukan penelitian tentang "Pengaruh Metode Pembelajaran Outdoor Learning Terhadap Motivasi dan Hasil Belajar Peserta Didik Pada Materi Interaksi Makhluk Hidup dengan Lingkungannya Kelas VII SMPN 15 Makassar”.

\section{METODE}

Penelitian ini menggunakan Jenis penelitian yang digunakan adalah quasi experiment. Penelitian yang dirancang untuk mendapatkan pengaruh penerapan Outdoor Learning terhadap motivasi dan hasil belajar peserta didik. Desain yang digunakan penelitian ini adalah Nonequivalent Grup Control Grup Design. Dalam desain ini terdapat dua kelompok. Kelompok pertama diberi perlakuan metode Outdoor Learning menggunakan model discovery learning $(\mathrm{X})$ dan kelompok yang lain tidak. Kelompok yang diberi perlakuan disebut kelompok eksperimen dan kelompok yang tidak diberi perlakuan disebut kelompok kontrol.

Penelitian ini dilaksanakan di SMP Negeri 15 Makassar tahun ajaran 2017/2018 yang terdiri dari 9 kelas dengan jumlah peserta didik sebanyak 270 orang. Pemilihan sample dilakukan dengan teknik accidental sampling sehingga diperoleh dua kelas sample yakni kelas $\mathrm{VIII}_{3}$ sebagai kelas eksperimen dan kelas $\mathrm{VIII}_{4}$ sebagai kelas kontrol yang masing-masing berjumlah 30 orang. Teknik pengumpulan data dilakukan dengan angket motivasi belajar dan tes hasil belajar.

Desain penelitian yang digunakan adalah Nonequivalent Control Group Design. (Sugiyono, 2016) bahwa pada desain ini kelompok eksperimen maupun kelompok kontrol tidak dipilih secara random. Kedua kelas tersebut diberi pretest-posttest dan hanya kelompok eksperimen yang mendapat perlakuan.

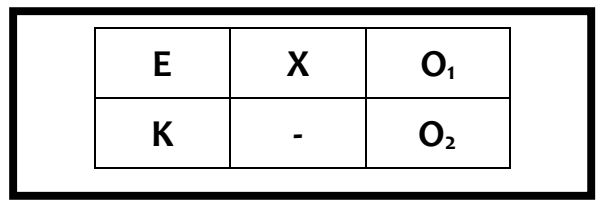

Gambar 1. Nonequivalent Control Group Design.

Instrumen yang digunakan dalam penelitian ini adalah angket motivasi belajar dan tes hasil belajar. Soal yang diberikan merupakan soal pilihan ganda.

Penelitian ini menggunakan analisis deskriptif dan analisis inferensial. Analisis statistik deskriptif bertujuan untuk mengetahui motivasi belajar dan tingkat hasil belajar peserta didik yang diajar dengan metode Outdoor Learning dan model pembelajaran Discovery Learning.

Analisis statistik inferensial dilakukan untuk menguji hipotesis penelitian dan dari hasil analisis itu akan ditarik suatu kesimpulan. Sebelum diberi perlakuan, perlu dianalisis dahulu melalui uji normalitas dan uji homogenitas. 


\section{HASIL DAN PEMBAHASAN}

\section{Analisis Statistik Desktiptif}

Analisis statistik deskriptif bertujuan untuk menunjukkan deskripsi tentang karektiristik distribusi skor motivasi dan hasil belajar dari masing-masing kelompok penelitian.

Tabel 1. Skor Statistik Deskriptif motivasi belajar Kelas Eksperimen dan kelas kontrol Peserta Didik Kelas VII SMP Negeri 15 Makassar.

\begin{tabular}{cccc}
\hline No. & Statistik & Kelas Kontrol & Kelas Eksperimen \\
\hline 1. & Jumlah sampel & 30.00 & 30.00 \\
2. & Skor tertinggi & 69.00 & 76.00 \\
3. & Skor terendah & 49.00 & 51.00 \\
4. & Skor rata-rata & 60.17 & 64.93 \\
5. & Standar deviasi & 5.77 & 6.89 \\
6. & Varians & 33.25 & 47.38 \\
\hline
\end{tabular}

Tabel 1 menunjukkan bahwa diperoleh bahwa skor motivasi belajar peserta didik kelas kontrol yang diajarkan tanpa menggunakan metode Outdoor Learning mencapai skor terendah 49,00 skor tertinggi 69,00, skor rata-rata yang dicapai adalah 60,17 dengan standar deviasi 5,77. Berdasarkan tabel 1 diperoleh bahwa skor motivasi belajar peserta didik kelas eksperimen yang diajarkan dengan menggunakan metode Outdoor Learning mencapai skor terendah 51,00 skor tertinggi 76,00 , skor rata-rata yang dicapai adalah 64,93 dengan standar deviasi 6,89.

Tabel 2. Skor Hasil Belajar Peserta Didik Kelas Eksperimen dan Kelas Kontrol

\begin{tabular}{ccrrrr}
\hline \multirow{2}{*}{ No. } & \multirow{2}{*}{ Statistik } & \multicolumn{2}{c}{ Kelas Kontrol } & \multicolumn{2}{c}{ Kelas Eksperimen } \\
\cline { 3 - 6 } & Pretest & Posttest & Pretest & Posttest \\
\hline 1. & Jumlah sampel & 30 & 30 & 30 & 30 \\
2. & Skor tertinggi & 11 & 18 & 12 & 19 \\
3. & Skor terendah & 4 & 10 & 4 & 12 \\
4. & Skor rata-rata & 7,46 & 14,4 & 6,70 & 16,23 \\
5. & Standar deviasi & 2,091 & 2,190 & 2,276 & 1,633 \\
6. & Varians & 4,372 & 4,796 & 5,180 & 2,666 \\
\hline
\end{tabular}

Berdasarkan Tabel 2 menunjukkan bahwa diperoleh bahwa Skor hasil belajar peserta didik pada pretest kelas kontrol dengan Skor tertinggi 11 dan Skor terendah 14, dan Skor rata-rata 7,46 dengan standar deviasi 2,091. Sedangkan pretest kelas eksperimen dengan Skor tertinggi 12 dan terendah 4 dan Skor rata-rata 6,70 dengan standar deviasi 2,276. Sedangkan pada posttest kelas eksperimen dengan Skor tertinggi 19 dan dengan Skor terendah 12 rata-rata Skor hasil belajar 16,23, dengan standar deviasi 1,633. Sedangkan Skor hasil belajar peserta didik kelas kontrol dengan Skor tertinggi 18 dan dengan Skor terendah 10, rata-rata Skor hasil belajar 14,4, dengan standar deviasi 2,190 . 
Tabel 3. Kategori N-gain kelas eksperimen dan kelas kontrol

\begin{tabular}{ccrrrr}
\hline & & \multicolumn{2}{c}{ Kelas Kontrol } & \multicolumn{2}{c}{ Kelas Eksperimen } \\
\cline { 3 - 6 } Interval & Kategori & Frekuensi & Persentase (\%) & Frekuensi & $\begin{array}{c}\text { Persentase } \\
(\%)\end{array}$ \\
\hline $0,70 \leq \mathrm{g} \leq 1,00$ & Tinggi & 7 & 23,33 & 17 & 56.67 \\
$0,30 \leq \mathrm{g}<0,70$ & Sedang & 21 & 70,00 & 3 & 43.33 \\
$0,00 \leq \mathrm{g}<0,30$ & Rendah & 2 & 6,67 & 0 & 0.00 \\
\hline Jumlah & & 30 & $\mathbf{1 0 0}$ & $\mathbf{3 0}$ & $\mathbf{1 0 0}$ \\
\hline
\end{tabular}

Berdasarkan Tabel 3 diketahui bahwa kategori N-gain hasil belajar peserta didik pada kriteria rendah yakni terdapat 3 peserta didik di kelas kontrol sedangkan o peserta didik di kelas eksperimen. Hal ini menunjukkan bahwa masih terdapat peserta didik yang hasil belajarnya tergolong rendah pada kelas kontrol, hal ini mungkin saja disebabkan oleh model pembelajaran konvensional yang diterapkan pada kelas kontrol belum mampu meningkatkan hasil belajar peserta didik tersebut yang bisa saja masih memiliki kesukaran untuk fokus dalam belajar dan memahami konsep yang diajarkan. Beralih pada kriteria sedang yakni kelas kontrol memperoleh persentase $70,00 \%$ yaitu 21 peserta didik yang terhitung lebih banyak dibandingkan di kelas eksperimen yang hanya sebanyak 13 peserta didik dengan persentase 43,33\%. Sedangkan untuk kriteria tinggi mencapai 56,67\% persentasenya pada kelas eksperimen sedangkan pada kelas kontrol persentasenya hanya sebesar $23,33 \%$. Kriteria tinggi pada kategori $\mathrm{N}$-gain tersebut menunjukkan bahwa terjadi peningkatan hasil belajar yang lebih signifikan pada kelas eksperimen yang diajar menggunakan metode outdoor learning dibandingkan dengan kelas kontrol yang diajar tanpa menggunakan metode outdoor learning.

\section{Analisis Statistik Inferensial}

Pengujian normalitas menggunakan Chi-Kuadrat $\left(\mathrm{X}^{2}\right)$ dengan derajat kebebasan tertentu dikurangi satu (dk=k1).

Tabel 4. Data Normalitas Motivasi Belajar Peserta Didik

\begin{tabular}{ccc}
\hline Data & Kelas Eksperimen & Kelas Kontrol \\
\hline$X^{2}$ Hitung & 6,6466 & 10,8107 \\
$X^{2}$ Tabel & 11,1 & 11,1 \\
Keterangan & $X^{2}$ Hitung $<X^{2}$ Tabel \\
& Data Terdistribusi Normal \\
\hline
\end{tabular}

Berdasarkan tabel 3 data yang diperoleh kelas eksperimen dan data kelas kontrol berdistribusi normal. Data yang diperoleh pada kelas eksperimen yaitu $X^{2}$ hitung $=6,6466<\mathrm{X}^{2}$ Tabel $=$ $11,1, \alpha=0,05$ dan derajat kebebasan $(\mathrm{dk})=\mathrm{k}-1=6-1=5$, data yang diperoleh pada kelas kontrol yaitu $X^{2}$ hitung $=10,8107<X^{2}$ Tabel $=11,1, \alpha=0,05$, dan derajat kebebasan $(\mathrm{dk})=k-1=6-1=5$.

Uji homogenitas menunjukan bahwa data Pada uji homogenitas data postest hasil belajar diperoleh Skor $F_{\text {hitung }}=1,40$ Sedangkan pada pengujian homogenitas data motivasi belajar diperoleh Skor $F_{\text {hitung }}=1,42$. Pada taraf nyata $\alpha=0,05$, maka $F_{\text {Tabel }}=F_{(0,05)(29 / 29)}=1,86$. Karena $F_{\text {hitung }} \leq F_{\text {Tabel }}$, maka dapat dinyatakan bahwa data dari kedua kelompok tersebut adalah homogen.

Hasil uji t-test menunjukkan bahwa hasil yang diperoleh data $t_{\text {hitung }}$ lebih besar dari data $t_{\text {tabel }}$ dengan skor 2,9035 >2,0017. Uji hipotesis dilakukan dengan menggunakan t-test atau uji-t. Kriteria pengujiannya adalah jika $t_{\text {hitung }}>t_{\text {tabel }}$, maka $\mathrm{H}_{\mathrm{o}}$ ditolak dan jika $\mathrm{t}_{\text {hitung }}<\mathrm{t}_{\text {tabel }}$ maka $\mathrm{H}_{\mathrm{o}}$ diterima. 


\section{Pembahasan}

Berdasarkan penelitian yang telah dilakukan pada materi pokok interaksi makhluk hidup dengan lingkunganya menunjukkan bahwa motivasi dan hasil belajar peserta didik pada penerapan metode outdoor learning lebih tinggi dibandingkan dengan Skor hasil belajar pada penerapan metode pembelajaran konvensional atau tanpa metode outdoor learning, dalam hal ini menggunakan model yang sama. Terdapat perbedaan hasil belajar antara kelas eksperimen dan kelas kontrol karena kelas eksperimen menggunakan metode outdoor learning, dimana dalam pembelajaran dengan metode outdoor learning peserta didik dalam memahami dan mempresentasikan hasil penemuan yang di lakukan peserta didik secara langsung, karena peserta didik melalui metode outdoor learning ini dapat melihat peristiwa secara langsung di lapangan, sehingga termotivasi untuk belajar yang kemudian dari motivasi belajar peserta didik yang tinggi kemudian akan berdampak pada hasil belajar peserta didik. Pada pembelajaran dengan metode outdoor learning ini peserta didik setelah memahami konsep akan mengaitkannya dengan hal yang ditemukannya secara langsung di lingkungan sekitar sekolah sehingga peserta didik dapat berinteraksi secara langsung dengan benda - benda ataupun ide-ide, sehingga dapat dirasakan manfaatnya dan pendidik hanya membimbing pserta didik. Sedangkan pada kelas kontrol yang menggunakan pembelajaran konvensional dengan model discovery learning, dimana pendidik yang melakukan proses pembelajaran, menunjukkan dan menjelaskan suatu proses sehingga peserta didik bersifat pasif dan kurang termotivasi dalam proses pembelajaran. Peserta didik juga hanya melakukan seluruh aktivitas pengamatan hanya berada pada lingkungan kelas.

Melalui pengamatan langsung objek pembelajaran melalui kegiatan outdoor learning, peserta didik dapat menemukan pengetahuannya sendiri dengan lebih aktif dalam bertanya tentang hal-hal yang belum diketahuinya dan menuangkannya dalam Lembar kerja Peserta Didik (LKPD) yang diberikan. Selain itu, peserta didik juga aktif dalam kegiatan diskusi, mulai dari menyumbangkan pendapat, menyampaikan hasil diskusi, mendengarkan pendapat teman saat diskusi, membuat catatan dari hasil diskusi sampai menggabungkan pendapat untuk menarik kesimpulan.

Hasil analisis deskriptif motivasi belajar peserta didik yang diajar dengan metode outdoor learning menunjukkan Skor rata-rata yang dicapai adalah 64,93 dan standar deviasi 6,89. Sedangkan pada kelas kontrol yang diajar tanpa menggunakan metode outdoor learning menunjukkan bahwa Skor rata-rata 60,17 dan standar deviasi 5,77. Hal ini berarti rata-rata motivasi belajar kelas eksperimen masih lebih unggul bila dibandingkan dengan rata-rata hasil belajar kelas kontrol. Sedangkan analisis deskriptif hasil belajar peserta didik pada kelas eksperimen yang diajar dengan metode outdoor learning menunjukkan Skor rata-rata yang dicapai adalah 81,17 dan standar deviasi 8,17. Sedangkan pada kelas kontrol yang diajar tanpa menggunakan metode outdoor learning menunjukkan bahwa Skor rata-rata 72,00 dan standar deviasi 10,95. Hal ini berarti rata-rata hasil belajar kelas eksperimen masih lebih unggul bila dibandingkan dengan rata-rata hasil belajar kelas kontrol.

Pengkategorian Skor motivasi peserta didik yang berdasarkan lampiran Kategori Skor motivasi peserta didik didapatkan bahwa Skor motivasi peserta didik pada kelas eksperimen yang berada pada kategori sangat tinggi berjumlah 4 orang, pada kategori tinggi sebanyak 9 orang. Sedangkan pada kelas kontrol yang berada pada kategori sangat tinggi tidak ada peserta didik yang berada pada kategori tersebut, dan pada kategori tinggi sebanyak 3 orang peserta didik.

Penelitian motivasi dan hasil belajar pada kelas eksperimen juga didukung dengan perhitungan persentase pencapaian indikator hasil belajar keseluruhan untuk materi interaksi makhluk hidup dengan lingkunganya pada kelas eksperimen lebih tinggi dibandingkan dengan kelas kontrol. Hal ini dapat dilihat pada rata-rata pencapaian indikator motivasi belajar kelas eksperimen dan kontrol sebesar 79,57\% dan 78,91\%. Adanya perbedaan peningkatan motivasi dan hasil belajar antara kelas eksperimen dan kelas kontrol disebabkan beberapa faktor. Salah satu 
diantaranya yaitu peserta didik di kelas eksperimen memiliki tambahan pengetahuan karena dapat melakukan penyelidikan langsung dan menemukan langsung konsep-konsep terkait dengan materi yang diajarkan, sedangkan pada kelas kontrol peserta didik cenderung pasif dan hanya menunggu penjelasan dari guru dan memiliki pengamatan yang terbatas.

Pencapaian indikator pertama pada kelas kontrol lebih tinggi dibandingkan dengan kelas eksperimen yaitu indikator hasrat dan keinginan berhasil hal ini disebabkan oleh kemampuan peserta didik dalam menjawab pertanyaan yang diberikan belum dapat dikuasai oleh peserta didik, peserta didik belum siap untuk menjawab pertanyaan baik disebabkan karena peserta didik belum belajar, penjelasan yang diberikan belum dapat dikuasai oleh peserta didik, ataupun peserta didik tidak bisa menerima maksud pertanyaan yang diberikan atau memang tingkat pemahaman peserta didik kurang.

Pencapaian indikator motivasi belajar pada indikator 2 pada kelas eksperimen lebih rendah karena peserta didik di dalam proses pembelajaran masih kurang daya tarik dan kebutuhan dalam belajarnya masih rendah. Peserta didik setelah diberikan motivasi sebelum atau saat pelajaran sedang berlangsung biasanya mereka hanya termotivasi pada saat diberikan motivasi saja setelah itu mereka akan kembali menjadi kurang aktif. Ini berarti motivasi yang ada dalam diri peserta didik masih rendah. Padahal peserta didik sangat membutuhkan peranan motivasi baik intrinsik maupun ekstrinsik. Peranan motivasi ini dibutuhkan untuk mengembangkan aktivitas dan senantiasa berinisiatif, serta memiliki ketekunan dalam melakukan kegiatan pembelajaran. Cara dan jenis menumbuhkan motivasi beraneka ragam dalam hal ini guru harus berhati-hati karena motivasi yang diberikan kadang-kadang tepat dan kadang-kadang juga kurang sesuai sehingga harus berhati-hati dalam menumbuhkan dan memberi motivasi bagi kegiatan belajar peserta didik. Motivasi peserta didik akan bangkit dan berkembang apabila mereka merasakan bahwa apa yang dipelajari itu bermanfaat. Jika peserta didik merasakan bahwa apa yang dipelajari itu bermanfaat bagi kehidupan mereka, maka mereka akan terdorong mempelajarinya karena memiliki hubungan dengan kebutuhan mereka, dan memiliki tujuan yang jelas. Artinya, motivasi belajar akan tumbuh jika peserta didik mengakui bahwa materi belajar mempunyai manfaat langsung secara pribadi.

Jika dilihat dari keseluruhan hasil analisis presentase pencapaian indikator motivasi belajar peserta didik perbedaan hasil presentase yang paling signifikan perbedaannya adalah indikator keenam yaitu adanya lingkungan belajar yang kondusif. Pada kelas kontrol diperoleh hasil presentase sebesar $80,3 \%$ dan pada kelas eksperimen diperoleh sebesar $90 \%$ hal ini menunjukkan bahwa kondisi di dalam kelas sangat mempengaruhi peserta didik dalam proses belajar. Kondisi kelas pada saat cuaca panas cukup sering mengganggu peserta didik dalam kegiatan belajar mengajar di kelas.

Motivasi sebagai penggerak di dalam diri peserta didik yang menimbulkan kegiatan belajar yang menjamin kelangsungan dari kegiatan belajar dan memberikan arah dalam kegiatan belajar, sehingga tujuan yang dikehendaki dapat tercapai. Sehingga semakin besar motivasinya maka akan semakin besar pula kesuksesan belajarnya. Sejalan dengan teori Sardiman (2012) yang menyatakan bahwa hasil belajar akan menjadi optimal kalau ada motivasi. Makin tepat motivasi yang diberikan, akan makin berhasil pula pelajaran itu.

Berdasarkan analisis data hasil penelitian sebagaimana telah diungkapkan di atas, ada beberapa hal yang perlu diperbaiki untuk mencapai hasil yang maksimal karena motivasi belajar siswa ada dua hal penting yang harus diperbaiki yaitu bagaimana agar siswa tidak malas untuk mengerjakan pekerjaan rumah dan menumbuhkan kepercayaan diri pada siswa bila mengerjakan soal ataupun LKPD di depan kelas. Motivasi belajar merupakan salah satu factor penentu keberhasilan belajar siswa yang paling menentukan dibandingkan dengan factor lainnya seperti ketersediaan sarana-prasarana, metode pembelajaran, dan lain sebagainya. Dikarenakan motivasi menjadi penggerak sekaligus pemberi arah kegiatan belajar, sehingga tujuan yang dikehendaki oleh subjek belajar dapat tercapai secara maksimal. 
Pencapaian skor hasil belajar peserta didik pada kelas eksperimen lebih tinggi dibandingkan kelas kontrol karena pada kelas kontrol masih ada beberapa peserta didik yang tidak memperhatikan proses belajar mengajar dan beberapa peserta didik memiliki tingkat pemahan yang masih rendah sehingga mengalami kekeliruan dalam mengerjakan soal. Peserta didik pada kelas kontrol juga masih kurang dalam kemampuan menganalisis soal tentang rantai makanan, serta peserta didik kelas kontrol masih kurang paham tentang posisi konsumen yang paling tinggi tingkatannya, masih banyak peserta didik yang menganggap bahwa posisi elang dalam rantai makanan merupakan konsumen yang paling tinggi kedudukannya data ini dapat dilihat dari jawaban peserta didik pada soal yang terkait.

Untuk memperkuat hasil dari analisis deskriptif diatas, maka dilakukan analisis statistik inferensial untuk membuktikan hipotesis yang diajukan. Sebelum melakukan uji-t, data harus berasal dari populasi yang terdistribusi normal dan homogen. Dari hasil pengujian yang dilakukan dengan menggunakan uji normalitas dan uji homogenitas diperoleh Skor motivasi dan hasil belajar dari dua kelas tersebut terdistribusi normal dan homogen, sehingga pengujian hipotesis dapat dilakukan dengan menggunakan uji-t. Hasil analisis inferensial dengan menggunakan uji-t motivasi belajar diperoleh Skor $t_{\text {hitung }}$ sebesar 2,9035 dan Skor $t_{\text {Tabel }}$ adalah 2,0017. Hal ini berarti Ho ditolak dan Ha diterima. Maka dapat disimpulkan bahwa terdapat perbedaan motivasi belajar yang signifikan pada peserta didik yang dibelajarkan melalui penerapan metode outdoor learning.

Dari hasil perhitungan Uji-t hasil belajar diperoleh $t$ hitung $>t$ Tabel yaitu 4,1898> 2,0017 sehingga Ho ditolak dan Ha diterima, maka dapat disimpulkan bahwa terdapat perbedaan hasil belajar yang signifikan pada peserta didik yang dibelajarkan melalui penerapan metode outdoor learning. Oleh karena itu, dapat disimpulkan bahwa terdapat pengaruh metode outdoor learning terhadap motivasi dan hasil belajar hasil belajar peserta didik kelas VII SMP Negeri 15 Makassar pada materi interaksi makhluk hidup dengan lingkunganya.

Adanya pengaruh positif ini pada kelas eksperimen dikarenakan pembelajaran dengan metode outdoor learning ini peserta didik bukan hanya belajar dengan menggunakan buku paket sebagai sumber belajar melainkan juga menggunakan alam sebagai sumber belajar dimana peserta didik dapat mengamati langsung objek yang dipelajari dari lingkungan sehingga peserta didik dapat bekerja sama mengidentifikasi ide-ide pokok atau konsep dari materi interaksi makhluk hidup dengan lingkungannya dan menghubungkan dengan kehidupan nyata di alam sehingga peserta didik aktif dan termotivasi untuk mengikuti pembelajaran dan memudahkan peserta didik memahami materi pelajaran karena sumber belajar bersifat konkret dan langsung. Selain itu pembelajaran dengan menggunakan metode outdoor learning ini dipadukan dengan model discovery learning sehingga perhatian peserta didik berpusat ke proses pembelajaran dimana model pembelajaran discovery learning merupakan model pembelajaran penemuan dalam hal ini peserta didik menemukan jawaban dari masalah-masalah yang dipecahkan oleh peserta didik itu sendiri. Pengaruh lain dari metode outdoor learning dengan model discovery learning ini terhadap peserta didik yaitu tingginya partsipasi aktif peserta didik dalam proses belajar mengajar terutama pada saat pengerjaan LKPD, hal ini disebabkan karena dalam pengerjaan LKPD peserta didik bersama dengan teman kelompoknya, mengajukan suatu masalah kemudian membuat jawaban sementara dilanjutkan dengan mngumpulkan data dan mengolah data itu sendiri kemudian sampai pada tahap menarik kesimpulan.

Sejati dkk (2016) menuliskan dalam penelitiannya bahwa keberhasilan penggunaan metode outdoor study dapat dilihat dari segi proses dan hasil. Proses menunjukkan aktivitas siswa dalam memahami, mempresentasikan, dan mempraktikkan bagian penulisan karya ilmiah. Metode outdoor study juga membangun keaktifan siswa dikarenakan pembelajaran outdoor study bersifat student centered dan menjawab rasa ingin tahu mereka. Pada kelas kontrol yang menggunakan pembelajaran konvensional mengalami peningkatan, tetapi tidak terlalu besar. Metode konvensional dalam bentuk ceramah (penjelasan konsep, prinsip, dan data) yang divariasikan dengan diskusi dan tanya jawab. 
Peneliti menyadari bahwa untuk meningkatkan motivasi dan hasil belajar peserta didik merupakan hal yang tidak mudah dilakukan. Hal ini dikarenakan memotivasi peserta didik berhubungan langsung dengan diri masing-masing peserta didik. Ada peserta didik yang memiliki motivasi belajar yang tinggi dan ada juga peserta didik yang kurang memiliki motivasi belajar. Kemampuan peserta didik yang masih terbatas khususnya pada pemahaman pola interaksi makhluk hidup dengan lingkungannya. Pengelolaan kelas, metode dan model pembelajaran serta media pembelajaran adalah hal-hal yang perlu diperhatikan dalam proses pembelajaran.

Hasil penelitian yang diperoleh didukung hasil penelitian yang terkait tentang metode outdoor learning terhadap motivasi dan hasil belajar yaitu Amtonurajah dan Muhsinatun (2015) menyatakan bahwa melalui outdoor activity dapat meningkatkan keterampilan sosial peserta didik dalam pembelajaran IPS pada peserta didik kelas VII A SMP Negeri 1 Kaligondang Kabupaten Purbalingga. Peningkatan ini terbukti dari hasil rerata keterampilan sosial peserta didik meningkat terus dari siklus I, II, dan III melalui outdoor activity, sebagai metode pembelajaran, ditempuh dengan cara melakukan observasi atau outdoor dengan tujuan untuk melakukan interaksi sosial secara langsung.

\section{KESIMPULAN}

Berdasarkan hasil analisis data maka dikemukakan kesimpulan sebagai berikut:

1. Terdapat pengaruh positif metode Outdoor Learning terhadap Motivasi belajar peserta didik kelas VII SMPN 15 Makassar materi pokok interaksi makhluk hidup dengan lingkungannya.

2. Terdapat pengaruh positif metode Outdoor Learning terhadap Hasil belajar peserta didik kelas VII SMPN 15 Makassar materi pokok interaksi makhluk hidup dengan lingkungannya.

\section{DAFTAR PUSTAKA}

Asrori, H.Muh. (2007). Psikologi Pembelajaran. Bandung: CV Wacana Prima.

Amtonurajah., Muhsinatun S. M. (2015). Peningkatan Keterampilan Sosial Siswa dalam Pembelajaran IPS Melalui Outdoor Activity di SMP Negeri 1 Kaligondang Kabupaten Perbalingga. Jurnal Pendidikan IPS. Volume 2. No.1, Maret 2015 (1-11).

Carrier, S. J. (2009). The Effects of outdoor Science Lesson with Elementary School Students on Preservice Teachers 'Self-Efficacy'. North California State University. Journal of Elementary Science Education. Vol.21. No. 2. (Spring 2009), pp. 35-48.@2009 Document and Publication Services, Western Illinois University.

Hamalik, O. (2001). Proses Belajar Mengajar. Jakarta : PT Bumi Aksara.

Hake, R. (1999). Analizyng Change/Gain Scores. http://www.physics.indiana.edu/. Gowa. Diakses pada tanggal 30 Juli 2017.

Haling, Abd., dkk. (2007). Belajar dan Pembelajaran. Makassar: Badan Penerbit Universitas Negeri Makassar.

Jufri, W. (2017). Belajar dan Pembelajaran SAINS Modal Dasar Menjadi Guru Profesional. Bandung: Pusaka Reka Cipta.

Kementrian Pendidikan dan Kebudayaan. (2014). Ilmu Pengetahuan Alam. Jakarta: Kementrian Pendidikan dan Kebudayaan.

Kunandar. (2014). Penilaian Autentik (Penilaian Hasil Belajar Peserta Didik Berdasarkan Kurikulum 2013) Suatu Pendekatan Praktis Disertai dengan Contoh. Jakarta: PT Rajagrafindo Persada.

Kurnianingsi, A., Darsiharjo., Enok M. (2015). Penggunaan Metode Pembelajaran Outdoor Study Terhadap Pemahaman Konsep Pelestarian Lingkungan Hidup Peserta Didik di MTsN Singaparna. Jurnal Pendidikan Geografi. Volume 15. Nomor 1. 
Mariyana, R., Ali N., dan Yeni R. (2010). Pengelolaan Lingkungan Belajar. Jakarta: Kencana Penada Media Group.

Trianto. (2010). Model Pembelajaran Terpadu Konsep, Strategi Dan Implementasinya Dalam Kurikulum Tingkat Satuan Pendidikan (KTSP). Jakarta: PT Bumi Aksara.

Ulum, B., \& Hidayah, R. (2015). Penerapan Model Pembelajaran Kooperatif Tipe Group Investigation (GI) Pada Materi Pokok Ikatan Kimia untuk Melatih Kemampuan Berpikir Kritis Siswa Kelas X Sma Widyah Darma Surabaya. Unesa Journal Of Chemical Education Vol 4 No.2, Pp. 156-152. Diakses pada tanggal 7 September 2017. Makassar.

Nugroho, A.A., dan Nur R.H. (2016). Implementasi Outdoor Learning Untuk Meningkatkan Hasil Belajar Kognitif Mahasiswa pada Mata Kuliah Sistematika Tumbuhan Tinggi. Jurnal Bioedukasi. Volume 9. Nomor 1.

Pratama, A.s., Dede M.I., dan Sulilowati. Pendekatan Outdoor Learning Jelajah Alam Sekitar (JAS) Untuk Meningkatkan Hasil Belajar Siswa dan Cinta Lingkungan Sekitar. Jurnal Antologi UPI. Volume Edisi. No.

Rahayu,Y.H., dan Ira Lestari. (2014). Penerapan Outdoor Learning Pada Siswa Kelas VIII Smp Negeri 8 Pontianak. Artikel Penelitian

Rohani, A. (2010). Pengelolaan Pengajaran Sebuah Penngantar Menuju Guru Profesional. Jakarta: Rineka Cipta.

Sani, R.A. (2015). Inovasi Pembelajaran. Jakarta: Bumi Aksara.

Sardiman. (2012). Interaksi dan Motivasi Belajar Mengajar. Jakarta: PT. Rajawali Pres.

Sejati, A.E., Sumarni., I. N. R. (2016). Pengaruh Metode Pembelajaran Outdoor Study Terhadap Kemampuan Menulis Karya IImiah Geografi SMA. Jurnal pendidikan: Teori, Penelitan, dan Pengembangan. Volume 1. Nomor 2.

Sudjana, N. (2011). Penilaian Hasil Proses Belajar Mengajar. Bandung: PT Remaja Rosdakarya.

Sugiyono. (2016). Metode Penelitian Pendidikan Pendekatan Kuantitatif, Kualitatif, dan R\&D Cetakan Ke-23. Bandung: Alfabeta.

Sukmadinata, N. S, (2004). Kurikulum dan Pembelajaran Kompetensi. Bandung: Kusuma Karya. Tiro, Muh. A. (2015). Dasar-Dasar Statistika Edisi Ketiga. Makassar: Andira Publisher.

Widiasworo, E., (2017). Strategi \& Metode Mengajar Siswa di Luar Kelas (Outdoor Learning) Secara Aktif, Kreatif, Inspiratif, \& Komunikatif. Yogyakarta: Ar-Ruzz Media.

\section{Sariayuningsi Amalia}

Mahasiswa Program Studi Pendidikan IPA FMIPA UNM, aktif melakukan penelitian pada bidang Pendidikan IPA, dapat dihubungi melalui pos-el: sariayuamalia12@gmail.com

\section{Abdul Mun'im}

Dosen Program Studi Pendidikan IPA FMIPA UNM, aktif melakukan penelitian pada bidang Pendidikan IPA.

\section{Sitti Rahma Yunus}

Dosen Program Studi Pendidikan IPA FMIPA UNM, aktif melakukan penelitian pada bidang Pendidikan IPA. 